\title{
Induced phagotrophy in the mixotrophic dinoflagellate Prorocentrum cordatum: exploring the role of cytoskeleton in prey ingestion
}

\author{
Mariia Berdieva, Alena Fel, Vera Kalinina, Sergei Skarlato \\ and Olga Matantseva
}

Institute of Cytology, Russian Academy of Sciences, St. Petersburg 194064, Russia

| Submitted September 9, 2020|Accepted September 29, 2020|

\begin{abstract}
Summary
The bloom-forming marine planktonic dinoflagellate Prorocentrum cordatum (syn. Prorocentrum minimum) is well known as a mixotrophic species; however, unraveling the cellular and molecular mechanisms of phagotrophy in this organism is still on the way. We focused on exploring the contribution of the cytoskeletal proteins to phagotrophy in P. cordatum. The drugs affecting cytoskeleton arrangement and functioning - cytochalasin D and nocodazole - were applied in the study. We tested the effect of pharmacological treatments on the frequency of ingestion of the prey cryptophyte Teleaulax amphioxeia by the grazer $P$. cordatum. Incubation with drugs resulted in a decrease in the fraction of dinoflagellate cells containing food vacuoles. The role of different cellular structures in the phagotrophy of prorocentroid dinoflagellates is discussed.
\end{abstract}

Key words: cytoskeleton, dinoflagellates, mixotrophy, phagotrophy, Prorocentrum cordatum, Teleaulax amphioxeia

\section{Introduction}

Mixotrophy is a combination of both autotrophy and heterotrophy in one cell. This trophic strategy is widespread among planktonic microorganisms (Stoecker et al., 2017; Flynn et al., 2019). Several functional groups of microorganisms that are defined by the origin of the photosynthetic elements (permanent chloroplasts, endosymbionts or cleptoplastids) and the balance of phago- and phototrophy can be distinguished (Mitra et al., 2016).
Dinoflagellates are the important component of marine and fresh water planktonic ecosystems worldwide. Approximately half of the known dinoflagellate species are heterotrophs, while the other half is able to photosynthesize possessing inheritable tertiary chloroplasts of different origin (Keeling, 2010) or using endosymbionts or kleptoplastids as photosynthetic elements. Many of these autotrophic dinoflagellates are mixotrophs and can ingest prey and consume dissolved organics (Stoecker et al., 2017). The degree to which different dinoflagellate 
species rely on phagotrophy as an additional source of carbon $(\mathrm{C})$, nitrogen $(\mathrm{N})$, phosphorus $(\mathrm{P})$, trace elements and vitamins varies even within one genus. In some taxa, grazing is vital, while the others use phagotrophy only for supplementation of deficient elements (Hansen, 2011). Dinoflagellates can feed on co-occurring microorganisms including cyanobacteria (Jeong et al., 2005a), ciliates, cryptophytes, raphidophytes, prymnesiophytes, diatoms, haptophytes and even other dinoflagellates (Hansen, 2011; Jang et al., 2016). Dinoflagellates have complex cell covering (termed "amphiesma") and therefore can ingest prey only through few special sites on the cell surface or using special structures (Schnepf and Elbrächter, 1992). The armored species possessing cellulosic thecal plates face an additional barrier, which obstructs the engulfment of prey (Kalinina et al., 2018).

Members of the genus Prorocentrum are of particular interest in this respect because they possess special cell architecture. They have two large thecal plates covering the cell body entirely as a shell and several small plates with only two tiny holes between them in the periflagellar region. Nevertheless, $P$. micans appears to engulf prey through the sutures on the cell side (Jacobson and Anderson, 1996; Jeong et al., 2005b). One can assume that cortical cytoskeleton plays essential role in this process.

Another well-known member of this genus, which forms massive harmful blooms (red tides) worldwide, is Prorocentrum cordatum (Ostenfeld) Dodge (syn. P. minimum (Pavillard) Schiller). P. cordatum is a mixotroph that has been shown to consume bacteria (Jeong et al. 2005a; Wikfors and Fernandez, 2013) and microalgae of different taxa (cryptophytes, raphidophytes, diatoms, haptophytes and dinoflagellates) less than $11.5 \mu \mathrm{m}$ in size (Hansen, 2011). Notably, it has strong preference to cryptophytes, in particular, Teleaulax amphioxeia (Conrad) Hill (Stoecker et al., 1997; Johnson, 2015). However, the phagocytosis of these dinoflagellates has not yet been fully unveiled. Meanwhile, the knowledge of cellular and molecular mechanisms behind the phagotrophy of $P$. cordatum is of crucial importance for understanding the general nutritional strategies of these bloom-forming dinoflagellates (e.g. Stoecker et al., 1997; Glibert et al., 2008, 2012; Matantseva et al., 2016, 2018; Pechkovskaya et al., 2020). Moreover, defining the performance of these protists in the pelagic food webs, particularly under the changing climate conditions (Glibert, 2020), will enhance the precision of ecological modeling and back up the future effective forecasting of the harmful red tides globally (Telesh et al., 2016, 2020; Skarlato et al., 2018; Khanaychenko et al., 2019).

To estimate the role of the cytoskeleton in the phagocytosis of $P$. cordatum, in this study we tested the effect of treatment with cytoskeletonspecific drugs, such as the actin depolymerizing agent cytochalasin $\mathrm{D}$ and microtubule stabilizing compound nocodazole, on the frequency of prey ingestion by the dinoflagellate cells.

\section{Material and methods}

\section{Cell culture}

The clonal culture of dinoflagellates Prorocentrum cordatum, strain CCAP 1136/16, was maintained in the protist collection at the Laboratory of Cytology of Unicellular Organisms (Institute of Cytology RAS). The batch culture was grown in artificial seawater-based f/2 medium (Guillard and Ryther, 1962; Kester et al., 1967) containing no silicate at salinity of 25 .

The culture of cryptophytes Teleaulax amphioxeia, strain GCEP01, isolated from Eel Pond (Falmouth, MA, USA) was kindly provided by Dr. Matthew D. Johnson in December 2019. The culture initially growing in the natural seawaterbased f/2 medium at salinity of 32 was subsequently acclimated to the artificial seawater-based $\mathrm{f} / 2$ medium for further cultivation. For the experiments, the cells were transferred and acclimated to salinity of 25 and grown at these conditions for at least two weeks prior to the experiments.

The dinoflagellate and cryptophyte cells were grown under a $12 \mathrm{~h} / 12 \mathrm{~h}$ light $/$ dark cycle at $100 \mu \mathrm{mol}$ photons $\mathrm{m}^{-2} \mathrm{~s}^{-1}, \mathrm{pH}$ 8.0-8.2 and $18^{\circ} \mathrm{C}$.

\section{EXPERIMENTAL PROCEDURES}

The approach used to induce phagotrophy in $P$. cordatum was based on the protocol developed by Johnson (2015). To achieve phosphorus deficiency, $P$. cordatum cells from the stock culture were harvested by centrifugation ( $800 \mathrm{~g}, 2 \mathrm{~min})$ and inoculated into Erlenmeyer glass flasks with fresh $\mathrm{f} / 2$ medium containing no phosphorus (-P) at a cell concentration of $3 \times 10^{4}$ cells ml- ${ }^{-1}$. The cells were allowed to grow for two weeks; their concentration

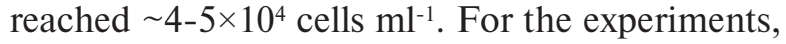
starved cells from the two-week culture were transferred into 24-well polystyrene plates with - $\mathrm{P}$ f/2 medium at a final concentration of $1 \times 10^{4}$ cells $\mathrm{ml}^{-1}$. 
The cryptophyte prey was added into the plates at a final concentration of $1 \times 10^{5}$ cells ml $^{-1}$ (grazer : prey ratio of $1: 10)$. P. cordatum cells were incubated with T. amphioxeia at the standard conditions (described above). The dinoflagellate cells incubated without cryptophytes were used as a negative control. The additional negative control was carried out using the dinoflagellate cells from the nutrient replete batch culture incubated with T. amphioxeia.

\section{DRUG TREATMENT}

To investigate the effect of pharmacological treatments on the frequency of prey ingestion, the cytoskeleton-specific drugs were added into the wells containing $P$. cordatum cells from the $-\mathrm{P}$ culture and $T$. amphioxeia cells (experimental samples) in $12 \mathrm{~h}$ and $18 \mathrm{~h}$ after the beginning of incubation. Cytochalasin D (C8273, Sigma-Aldrich, St. Louis, MO, USA) was tested at a final concentration of $5 \mu \mathrm{g}$ $\mathrm{ml}^{-1}$, nocodazole (M1404, Sigma-Aldrich, St. Louis, MO, USA) - at a final concentration of $10 \mu \mathrm{g} \mathrm{ml}^{-1}$. The stock solutions of drugs were prepared using DMSO as a solvent. Cells incubated with the same volume of DMSO were used as a procedural control. The well containing $P$. cordatum and T. amphioxeia cells not subjected to the drug treatment was used as a positive control. In the negative controls, the drugs were also not added to the medium. The incubation time with the drugs was $6 \mathrm{~h}$; the control wells were incubated for the same time. Thus, the dinoflagellate cells were incubated with prey for $18 \mathrm{~h}$ or $24 \mathrm{~h}$ after the initiation of experiments and prior to fixation.

Cell fiXation, microscopy AND ANALYTICAL PROCEDURES

After the incubation with drugs, samples were fixed in the formaldehyde solution added directly to the culture medium (final concentration 1\%) at $4{ }^{\circ} \mathrm{C}$ at least for $30 \mathrm{~min}$, centrifuged at $3000 \mathrm{~g}$ for 2 min and washed in PBS containing $100 \mathrm{mM}$ glycine. Then cells were treated with $96 \%$ ethanol for $1-1.5 \mathrm{~h}$. The samples were washed in PBS and harvested by centrifugation. The preparations were embedded in the glycerol-PBS mixture and examined by the light microscope (Leica DM2500, Leica-Microsystems, Wetzlar, Germany) using phase contrast and fluorescence (N2.1 filter cube).

To determine the frequency of prey capture, $P$. cordatum cells with orange or red bodies in the cytoplasm - food vacuoles containing cryptophyte prey - and cells containing no food were counted.

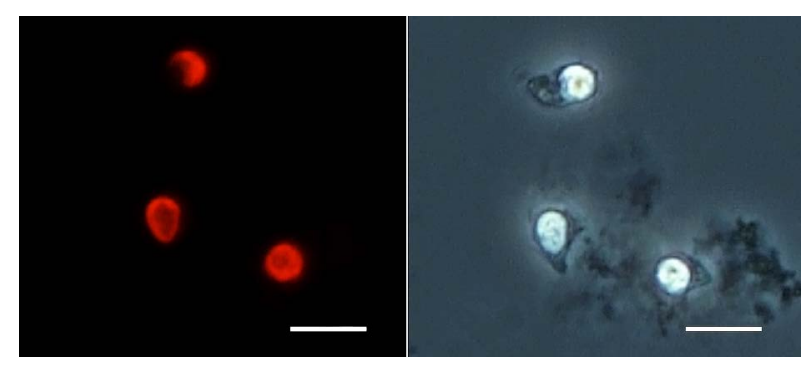

Fig. 1. The cryptophyte Teleaulax amphioxeia cells in fixed and treated with ethanol samples (fluorescent and phase contrast microscopy). Scale bars: $10 \mu \mathrm{m}$.

The percentage of cells with food vacuoles was calculated. For each sample, at least 200 P. cordatum cells were counted.

The experiment was conducted in triplicates.

The images obtained during the study of preparations were cropped using Image J (https://imagej. nih.gov/ij/). The Adobe Photoshop 21.0.1 (https:// www.adobe.com/) software was used to adjust relative contrast and brightness of the images.

\section{STATISTICAL ANALYSIS}

MaxStat Lite 3.60 software (https://maxstat.de/ en/home-en/) was used for the statistical analysis. Mean values were compared using the unpaired two-tailed t-test.

\section{Results}

The cryptophyte Teleaulax amphioxeia cells demonstrated bright orange or red autofluorescence due to the presence of phycoerythrin, which remained after the ethanol treatment of the samples (Fig. 1). At the same time, we observed no pigment autofluorescence of the dinoflagellate cells themselves. The dinoflagellate cells containing orange or red bodies in the cytoplasm - food vacuoles with $T$. amphioxeia - were revealed in the experimental samples and in the positive control (Fig. 2). The number and size of food vacuoles varied; cells contained from one (Fig. 2, A) to several (Fig. 2, B-F), even to about a dozen of small or large vacuoles. It was difficult to verify their exact number due to overlapping fluorescence from distinct vacuoles.

We did not observe dinoflagellate cells with such orange or red bodies in the cytoplasm, neither in the negative control in which no prey was added 

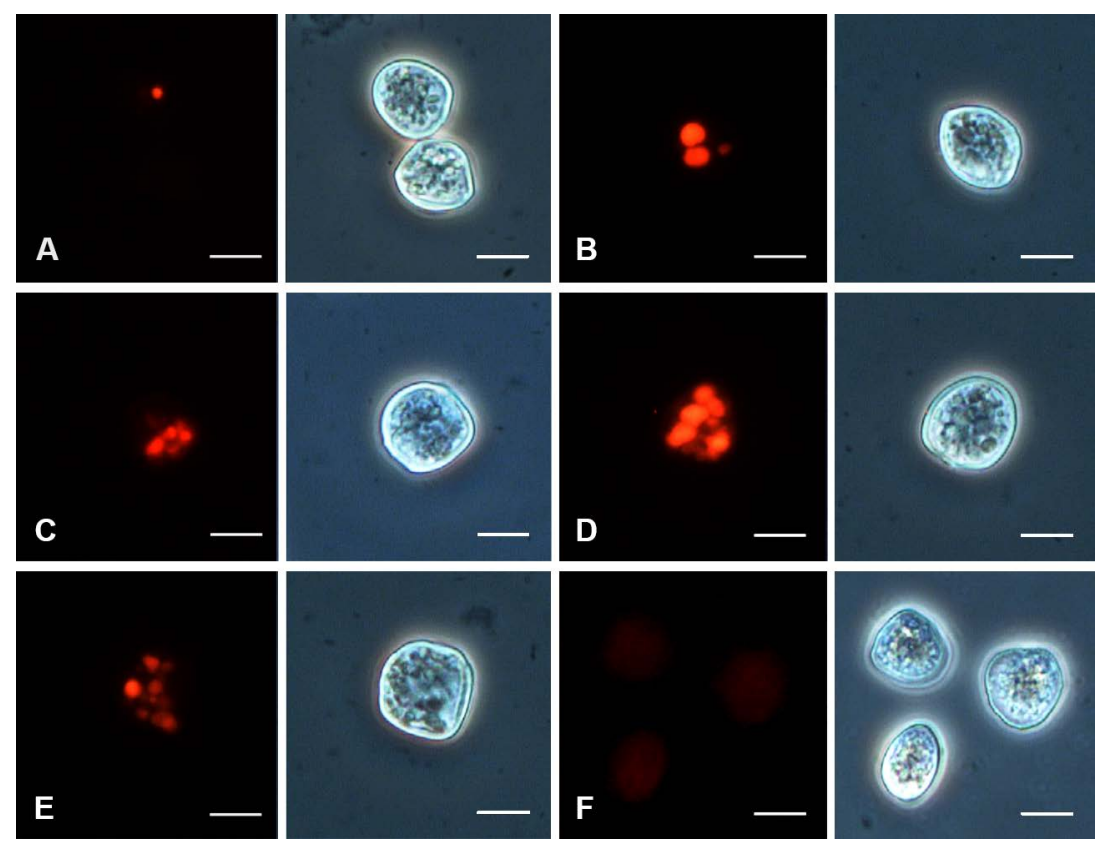

Fig. 2. The dinoflagellate Prorocentrum cordatum cells (grazer) with orange or red food vacuoles containing cryptophyte Teleaulax amphioxeia cells (prey) (fluorescent and phase contrast microscopy). A-E - Cells with food vacuoles varying in number and size, which were observed in samples (either treated with drugs or not) containing prey and grazer from nutrient depleted experimental culture; F - dinoflagellate cells having no food vacuoles, which were observed in samples containing grazers from nutrient replete batch culture (additional control) or no prey (negative control). The red autofluorescence in P. cordatum cells was absent. Scale bars: $10 \mu \mathrm{m}$.

nor in the additional control with dinoflagellates from the nutrient replete batch culture. The red autofluorescence in P. cordatum cells was also absent (Fig. 2, F).

The frequency of prey ingestion was rather low. In the positive control, the fraction of cells containing food vacuoles was about $1.6 \%$ in 18 $\mathrm{h}$ and $3.2 \%$ in $24 \mathrm{~h}$ after beginning of incubation with prey (Fig. 3). Nevertheless, it was possible to detect the effect of the cytoskeleton-specific drugs on the ability of $P$. cordatum to ingest prey. In 24hour samples, the treatment with cytochalasin D decreased the fraction of cells with food vacuoles by almost two and a half times (Fig. 3, A). The effect of nocodazole was more pronounced - the fraction of feeding cells was reduced by almost five times (Fig. 3, A). In both cases, the effect was statistically significant (unpaired t-test: $\mathrm{p}<0.01$ ). In 18-hour samples, treatment with drugs also decreased frequency of prey capture. In particular, the incubation with nocodazole resulted in two-fold reduction of the fraction of cells containing food vacuoles (Fig. 3, B). However, these differences were not statistically significant (unpaired t-test: $p>0.05$ ). Treatment with DMSO did not show any differences with positive control (Fig. 3).

\section{Discussion}

This study presents the results of experiments aimed at unveiling the possible role of cytoskeletal elements in the induced phagocytosis in the dinoflagellate Prorocentrum cordatum. This species is known to be mixotrophic, that is combining phototrophy and phagotrophy (Stoecker et al., 1997; Stoecker, 1998; Johnson, 2015). To induce transition to phagotrophy we used phosphorous starvation. Inorganic nutrient (such as $\mathrm{P}, \mathrm{N}$ or $\mathrm{Fe}$ ) limitation is a common factor used to induce phagotrophy or increase its contribution to the nutrition in protists, including dinoflagellates (Stoecker, 1998). P-starvation has been proven as an effective tool to induce mixotrophy in P. cordatum, in contrast to N-starvation (Johnson, 2015).

The cryptophyte Teleaulax amphioxeia was used as prey in our study. The preferable ingestion of this organism (this particular strain) by $P$. minimum $(=P$. cordatum) was previously demonstrated by Johnson (2015). The author revealed that at least $30 \%$ of dinoflagellate cells contained food vacuoles when in the presence of T. amphioxeia. In our experiments, the frequency of prey capture was much lower. In the 


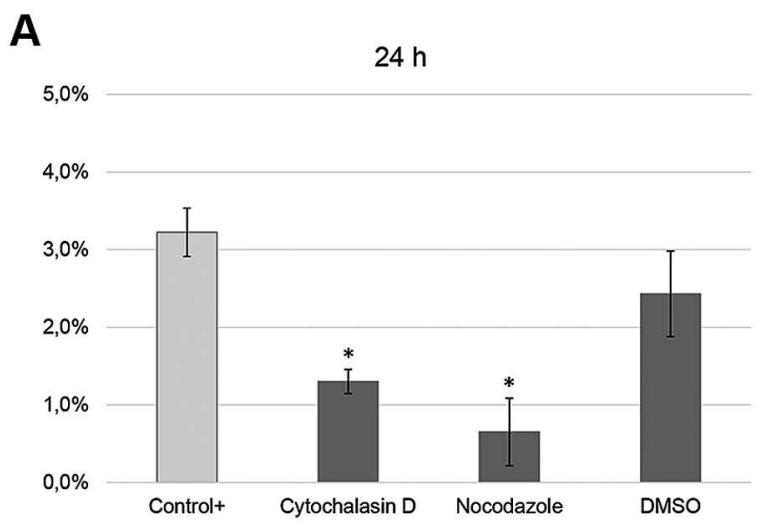

B
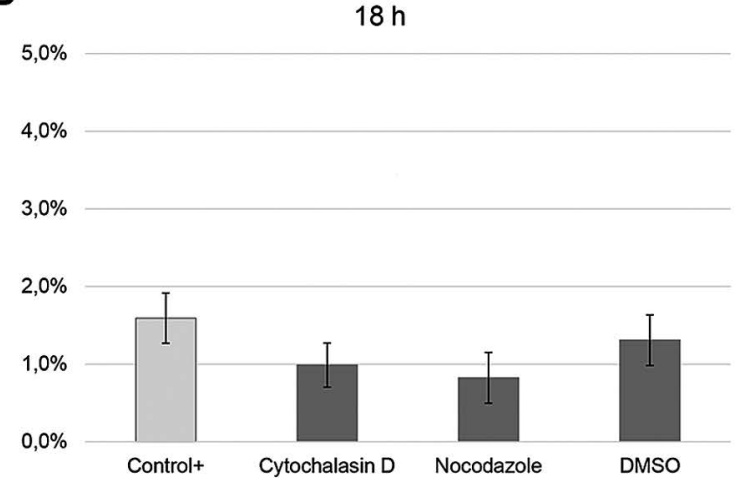

Fig. 3. The effect of 6-h treatment with cytochalasin $\mathrm{D}$ and nocodazole on the number of Prorocentrum cordatum cells that ingest the cryptophyte Teleaulax amphioxeia cells: A - Samples fixed in 24 $\mathrm{h}$ after the beginning of incubation with prey; $\mathrm{B}$ - samples fixed in $18 \mathrm{~h}$ after the beginning of incubation with prey. Control+ - samples with grazer and prey cells that were not exposed to the drug treatment. DMSO - samples treated with DMSO used as a solvent for drugs. In the negative and additional controls, cells with food vacuoles were not found (not shown in bar graphs). Shown is the percentage of cells containing orange or red food vacuoles (mean values \pm standard error of the mean). Asterisks indicate statistically significant differences obtained by comparison with Control+ (unpaired t-test, $\mathrm{n}=3, \mathrm{p}<0.01$ ).

preliminary series of experiments, we occasionally managed to induce phagotrophy in a larger fraction of dinoflagellate cells, but those results were not sustainable (not shown). This discrepancy may be due to the differences between the $P$. cordatum strains used or the state of the stock cultures. The long-term cultivation without available prey also could affect their ability to feed phagotrophically. The drastic decrease of frequency of prey ingestion in autotrophically grown substrain in comparison with the substrain cultivated with periodically offered prey has been shown for Alexandrium pseudogonyaulax (Blossom and Hansen, 2020). In the experiments of Johnson (2015), the low frequency of prey capture was observed when in the presence of other cryptophyte species. In other studies, the fraction of cells with food inclusions was also rather low in different strains of P. cordatum $(\mathrm{Li}$ et al., 1996).

Cryptophytes have a special pigment composition consisting of chlorophylls $a$ and $c$, carotenoids and phycobiliproteins, in particular, phycoerythrin (van der Weij-De Wit et al., 2006). Such a characteristic makes them convenient food object to study feeding behavior of dinoflagellates. The reports showing that ethanol does not extract phycobiliproteins from the algae cells can be found in the literature (Ó Carra and Ó Heocha, 1966). In our experiments, treatment with ethanol effectively bleached the autofluorescence of dinoflagellate cells but did not affect cryptophytes, which made it easy to detect food vacuoles in the cytoplasm of their consumers.

In Prorocentrum cells, actin filaments form a dense layer in the cortical cytoplasm. The cortical microtubules, by contrast, are absent (Schnepf et al., 1990; Berdieva et al., 2018). The presence of microtubular cytoskeletal elements is limited only to the flagellar apparatus, the spindle apparatus in the dividing cells and the structure identified as a microtubular basket (we will address this structure in more details below). Such a pattern of cytoskeleton organization was demonstrated in cells of $P$. micans and P. cordatum (Faust, 1974; Schnepf and Winter, 1990; Schnepf et al., 1990; Soyer-Gobillard et al., 1996; Berdieva et al., 2018) and may be assumed the same in other prorocentroid species. F-actin was found to be involved in the cytokinesis and proper formation of the thecal plates in $P$. micans cells (Schnepf, 1988; Schnepf et al., 1990) and play a crucial role in the stressor-induced ecdysis - a cell covering rearrangement process - in $P$. cordatum (Berdieva et al., 2018; Kalinina et al., 2020; Matantseva et al., 2020).

In our experiments, treatment with cytochalasin $\mathrm{D}$, which inhibits actin polymerization, decreased the number of $P$. cordatum cells containing food vacuoles. This result is consistent with the descrip- 
tion of feeding behavior of a grazer P. micans presented by Jeong with co-authors (Jeong et al., 2005b). They observed dinoflagellates engulfing prey cells through the sutures on the different sides of their bodies. Actin filaments can provide contractility of the cortical cytoplasm zone ensuring the opening of thecal plates and, presumably, formation of a temporary "cytostome".

Moreover, actin remodeling is considered to be a fundamental basis of the phagocytosis process in eukaryotic cells (May and Machesky, 2001). Being involved in diverse signaling pathways in various organisms, actin rearrangement provides proper internalization of captured particles (May and Machesky, 2001). Nevertheless, the hypothesis on the actin-dependent phagocytosis in Prorocentrum sp. requires further investigations. Jacobson and Anderson (Jacobson and Anderson, 1996) assumed that dinoflagellates, including prorocentroids, when directly ingesting entire large prey, could do it by opening or dissolving of the selected thecal plates, or via undergoing ecdysis. The latter is also consistent with the involvement of $\mathrm{F}$-actin in the feeding process and merits investigation. However, neither Jeong with co-authors (Jeong et al., 2005b) described shedding of amphiesma in feeding dinoflagellates, nor we observed relevant morphological changes in $P$. cordatum cells.

Nocodazole is an agent that affects microtubule polymerization. Its effect on the frequency of prey capture was even more pronounced compared to cytochalasin D. At the same time, according to our observations, it had no significant impact on motility of $P$. cordatum and T. amphioxeia cells. This is in line with the fact that nocodazole does not affect the structure of flagella dramatically. It was shown that the nocodazole treatment resulted in the flagella shortening in Giradia (Dawson et al., 2007) and did not influence the axonema length in Chlamydomonas (Wang et al., 2013). The effect of nocodazole on prey ingestion should be discussed with regard to the presence of the microtubular basket in $P$. cordatum and $P$. micans cells. This structure has been assumed a non-emerged (retracted) feeding tube, or peduncle (Schnepf and Winter, 1990). The peduncle is a long cytoplasmic protrusion used to pierce the cell covering of the prey and to suck its cytoplasm. This modification of phagocytosis is termed "myzocytosis" (Schnepf and Elbrächter, 1992). It has been described in a number of naked and armored dinoflagellates from different genera (see for review: Schnepf and Elbrächter, 1992; Hansen and Calado, 1999). The peduncle is stiffened by the overlapping rows of microtubules, which probably provide its elongation in active state. These microtubules - microtubular basket structure - make peduncle recognizable when retracted (Hansen and Calado, 1999). However, in some cases, despite the presence of microtubular basket/peduncle, its role as a feeding structure was not confirmed (Hansen and Calado, 1999) and thus remains unknown. In other cases, this structure was only visible during the initial stages of the feeding event (Larsen, 1988).

Current data regarding the feeding process in Prorocentrum spp. allow concluding that these species apparently do not feed myzocytotically. Nevertheless, we admit possible participation of its peduncle-like structure in phagocytosis. This structure can be responsible for the primary connection with a prey cell at the initial stages of the feeding event. It is also possible that microtubular basket/peduncle is a highly dynamic structure which is developed and quickly disassembled during phagotrophy process in $P$. cordatum cells. Taken together, this could be a possible explanation for the observed effect of the nocodazole treatment on ingestion of cryptophyte cells by P. cordatum.

To sum up, our results contribute to elucidating the mechanism of phagotrophy in P. cordatum cells (and, presumably, in other Prorocentrum species as well). The accumulation of data on the role of cytoskeletal elements in the feeding process in dinoflagellates will allow to focus not only on exploring mechanisms of prey consuming but also on unveiling the signaling pathways controlling their nutrition. Ultimately, this knowledge is critical for understanding the flexibility of dinoflagellate nutritional modes and, in turn, disclosing its crucial role in the effective environmental adaptation strategies of these bloom-forming marine protists of global ecological importance.

\section{Acknowledgements}

We are grateful to Dr. Matthew D. Johnson who generously provided Teleaulax amphioxeia culture and made this study possible. The research was funded by the Russian Science Foundation, project 19-14-00109. Usage of equip-ment was funded in part by the Budgetary Program N 01242019-0005 at the Institute of Cytology RAS. 


\section{References}

Berdieva M., Pozdnyakov I., Matantseva O., Knyazev N. and Skarlato S. 2018. Actin as a cytoskeletal basis for cell architecture and a protein essential for ecdysis in Prorocentrum minimum (Dinophyceae, Prorocentrales). Phycol. Res. 66, 127-136.

Blossom H.E. and Hansen P.J. 2020. The loss of mixotrophy in Alexandrium pseudogonyaulax: Implications for trade-offs between toxicity, mucus trap production, and phagotrophy. Limnol. Oceanogr. 9999, 1-15.

Dawson S.C., Sagolla M.S., Mancuso J.J., Woessner D.J., House S.A., Fritz-Laylin L. and Cande W.Z. 2007. Kinesin-13 regulates flagellar, interphase, and mitotic microtubule dynamics in Giardia intestinalis. Eukaryot. Cell. 6, 2354-2364.

Faust M.A. 1974. Micromorphology of a small dinoflagellate Prorocentrum mariae-lebouriae (Parke and Ballatine) comb. nov. J. Phycol. 10, 315-322.

Flynn K.J., Mitra A., Anestis K., Anschütz A.A., Calbet A., Ferreira G.D., Gypens N., Hansen P.J., John U. and Martin J.L. 2019. Mixotrophic protists and a new paradigm for marine ecology: where does plankton research go now? J. Plankton Res. 41, 375-391.

Glibert P.M. 2020. Harmful algae at the complex nexus of eutrophication and climate change. Harmful Algae. 91, 101583.

Glibert P.M., Burkholder J.M. and Kana T.M. 2012. Recent insights about relationships between nutrient availability, forms, and stoichiometry, and the distribution, ecophysiology, and food web effects of pelagic and benthic Prorocentrum species. Harmful Algae. 14, 231-259.

Glibert P.M., Mayorga E. and Seitzinger S. 2008. Prorocentrum minimum tracks anthropogenic nitrogen and phosphorus inputs on a global basis: application of spatially explicit nutrient export models. Harmful Algae. 8, 33-38.

Guillard R.R.L. and Ryther J.H. 1962. Studies of marine planktonic diatoms: I. Cyclotella nana Hustedt, and Detonula confervacea (Cleve) Gran. Can. J. Microbiol. 8, 229-239.

Hansen P.J. 2011. The role of photosynthesis and food uptake for the growth of marine mixotrophic dinoflagellates. J. Eukaryot. Microbiol. 58, 203-214.

Hansen P.J. and Calado A.J. 1999. Phagotrophic mechanisms and prey selection in free-living dinoflagellates. J. Eukaryot. Microbiol. 46, 382-389.

Jacobson D.M. and Anderson D.M. 1996. Widespread phagocytosis of ciliates and other protists by marine mixotrophic and heterotrophic thecate dinoflagellates. J. Phycol. 32, 279-285.

Jang S.H., Jeong H.J., Lim A.S., Kwon J.E. and Kang N.S. 2016. Feeding by the newly described heterotrophic dinoflagellate Aduncodinium glandula: having the most diverse prey species in the family Pfiesteriaceae. Algae-Seoul. 31, 17-31.

Jeong H., Park J., Nho J., Park M., Ha J., Seong K., Jeng C., Seong C., Lee K. and Yih W. 2005a. Feeding by red-tide dinoflagellates on the cyanobacterium Synechococcus. Aquat. Microb. Ecol. 41, 131-143.

Jeong H., Yoo Y., Park J., Song J., Kim S., Lee S., Kim K. and Yih W. 2005b. Feeding by phototrophic red-tide dinoflagellates: five species newly revealed and six species previously known to be mixotrophic. Aquat. Microb. Ecol. 40, 133-150.

Johnson M.D. 2015. Inducible mixotrophy in the dinoflagellate Prorocentrum minimum. J. Eukaryot. Microbiol. 62, 431-443.

Kalinina V., Berdieva M. and Matantseva O. 2020. The role of the cytoskeleton in the ecdysis of the dinoflagellate Prorocentrum minimum. Protistology. 14, 38-44.

Kalinina V., Matantseva O., Berdieva M. and Skarlato S. 2018. Trophic strategies in dinoflagellates: How nutrients pass through the amphiesma. Protistology. 12, 3-11.

Keeling P.J. 2010. The endosymbiotic origin, diversification and fate of plastids. Phil. Trans. R. Soc. B. 365, 729-748.

Kester D.R., Duedall I.W., Connors D.N. and Pytkowicz R.M. 1967. Preparation of artificial seawater. Limnol. Oceanogr. 12, 176-179.

Khanaychenko A.N., Telesh I.V. and Skarlato S.O. 2019. Bloom-forming potentially toxic dinoflagellates Prorocentrum cordatum in marine plankton food webs. Protistology. 13, 95-125.

Larsen J. 1988. An ultrastructural study of Amphidinium poecilochroum (Dinophyceae), a phagotrophic dinoflagellate feeding on small species of cryptophytes. Phycologia. 27, 366-377.

Li A., Stoecker D.K., Coats D.W. and Adam E.J. 1996. Ingestion of fluorescently labeled and phycoerythrin-containing prey by mixotrophic dinoflagellates. Aquat. Microb. Ecol. 10, 139-147.

May R.C. and Machesky L.M. 2001. Phagocytosis and the actin cytoskeleton. J. Cell Sci. 114, 1061-1077.

Matantseva O., Berdieva M., Kalinina V., Pozdnyakov I., Pechkovskaya S. and Skarlato S. 2020. Stressor-induced ecdysis and thecate cyst formation in the armoured dinoflagellates Prorocentrum cordatum. Sci. Rep. 10, 18322. 
Matantseva O., Pozdnyakov I., Voss M., Liskow I. and Skarlato S. 2018. The uncoupled assimilation of carbon and nitrogen from urea and glycine by the bloom-forming dinoflagellate Prorocentrum minimum. Protist. 169 (5), 603-614.

Matantseva O., Skarlato S., Vogts A., Pozdnyakov I., Liskow I., Schubert H. and Voss M. 2016. Superposition of individual activities: urea-mediated suppression of nitrate uptake in the dinoflagellate Prorocentrum minimum revealed at the population and single-cell levels. Front. Microbiol. 7, 1310.

Mitra A., Flynn K.J., Tillmann U., Raven J.A., Caron D., Stoecker D.K., Not F., Hansen P.J., Hallegraeff G. and Sanders R. 2016. Defining planktonic protist functional groups on mechanisms for energy and nutrient acquisition: incorporation of diverse mixotrophic strategies. Protist. 167, 106-120.

Ó Carra P. and Ó Heocha C. 1966. Bilins released from algae and biliproteins by methanolic extraction. Phytochemistry. 5, 993-997.

Pechkovskaya S.A., Knyazev N.A., Matantseva O.V., Emelyanov A.K., Telesh I.V., Skarlato S.O. and Filatova N.A. 2020. Dur3 and nrt2 genes in the bloom-forming dinoflagellate Prorocentrum minimum: transcriptional responses to available nitrogen sources. Chemosphere. 241, 125083.

Schnepf E. 1988. Cytochalasin D inhibits completion of cytokinesis and affects theca formation in dinoflagellates. Protoplasma. 143, 22-28.

Schnepf E. and Elbrächter M. 1992. Nutritional strategies in dinoflagellates. Eur. J. Protistol. 28, $3-24$.

Schnepf E. and Winter S. 1990. A microtubular basket in the armoured dinoflagellate Prorocentrum micans (Dinophyceae). Arch. Protistenkd. 138, 89 -91 .

Schnepf E., Winter S., Storck I. and Quader H. 1990. A complementary experimental study of cell division in the dinoflagellate Prorocentrum micans. Eur. J. Protistol. 25, 234-242.

Skarlato S.O., Telesh I.V., Matantseva O.V., Pozdnyakov I.A., Berdieva M.A., Schubert H., Filatova N.A., Knyazev N.A. and Pechkovskaya S.A. 2018. Studies of bloom-forming dinoflagellates
Prorocentrum minimum in fluctuating environment: contribution to aquatic ecology, cell biology and invasion theory. Protistology. 12, 113-157.

Soyer-Gobillard M.-O., Ausseil J. and Géraud M.-L. 1996. Nuclear and cytoplasmic actin in dinoflagellates. Biol. Cell. 87, 17-35.

Stoecker D.K. 1998. Conceptual models of mixotrophy in planktonic protists and some ecological and evolutionary implications. Eur. J. Protistol. 34, 281-290.

Stoecker D.K., Hansen P.J., Caron D.A. and Mitra A. 2017. Mixotrophy in the marine plankton. Ann. Rev. Mar. Sci. 9, 311-335.

Stoecker D., Li A., Coats D., Gustafson D. and Nannen M. 1997. Mixotrophy in the dinoflagellate Prorocentrum minimum. Mar. Ecol. Prog. Ser. 152, $1-12$.

Telesh I.V., Khanaychenko A.N. and Skarlato S.O. 2020. The interplay of two invaders: can blooms of the potentially toxic dinoflagellates Prorocentrum cordatum be downregulated by the neritic copepods Acartia tonsa? Protistology. 14, 103-111.

Telesh I.V., Schubert H. and Skarlato S.O. 2016. Ecological niche partitioning of the invasive dinoflagellate Prorocentrum minimum and its native congeners in the Baltic Sea. Harmful Algae. 59, $100-111$.

Van der Weij-De Wit C.D., Doust A.B., van Stokkum I.H.M., Dekker J.P., Wilk K.E., Curmi P.M.G., Scholes G.D. and van Grondelle R. 2006. How energy funnels from the phycoerythrin antenna complex to photosystem I and photosystem II in cryptophyte Rhodomonas CS24 cells. J. Phys. Chem. B. 110, 25066-25073.

Wang L., Piao T., Cao M., Qin T., Huang L., Deng H., Mao T. and Pan J. 2013. Flagellar regeneration requires cytoplasmic microtubule depolymerization and kinesin-13. J. Cell Sci. 126, 1531-1540.

Wikfors G.H. and Fernandez E. 2013. Induced bacteriovory in a declining culture of the mixotrophic dinoflagellate Prorocentrum minimum (Pavillard) Schiller. Int. J. Ecol. 2013, 1-5.

Address for correspondence: Mariia Berdieva. Institute of Cytology of the Russian Academy of Sciences, Laboratory of Cytology of Unicellular Organisms, Tikhoretsky Ave. 4, 194064 St. Petersburg, Russia; e-mail: maria.berd4@yandex.ru 